\title{
Bir Propaganda Aracı Olarak Türkiye'de Sinema: Atatürk Dönemi
}

\section{Cinema as a Propaganda Means: Ataturk Cycle}

\author{
Meltem TEKEREK ${ }^{1}$ (D)
}

'Dr., Ankara, Türkiye

ORCID: M.T. 0000-0001-5212-5313

Sorumlu yazar/Corresponding author: Meltem Tekerek,

Ankara, Türkiye

E-posta/E-mail:

meltemtekerek@gmail.com

Başvuru/Submitted: 05.03.2020 Revizyon Talebi/Revision Requested: 07.05.2020

Son Revizyon/Last Revision Received: 20.05.2020

Kabul/Accepted: 20.05 .2020

Atıf/Citation: Tekerek, M. (2020). Bir Propaganda Aracı Olarak Türkiye'de Sinema: Atatürk Dönemi. Yakın Dönem Türkiye Araştırmaları-Recent Period Turkish Studies, 37: 181-204.

https://doi.org/10.26650/YTA2020-007

\begin{abstract}
ÖZ
İlk olarak Osmanlı'nın son zamanlarında Türkiye'ye giren sinema, Cumhuriyet ilan edilinceye kadar olan süreçte bazı ilklerini yaşadı. Birinci Dünya Savaşı sırasında propaganda gücü fark edilen sinema; uzun savaş yıllarından sonra Türkiye'de Cumhuriyet ilan edildiğinde oldukça iptidai bir mirasa sahipti. Buna rağmen Cumhuriyet'in ilk yıllarında sinemanın propaganda ve telkin gücü konusunda farkındalık yüksekti. Ekonomik ve teknik sınırlılık sinemadan ancak belli bir ölçüde faydalanmayı mümkün kılabildi. Ancak başlangıçta edinilen bazı tecrübeler 1930'lu yıllardan itibaren Türkiye'de sinemanın alt yapısını oluşturmaya başladı. Sinema mevzuatı da bu dönemde oluşurken, sinemanın kitleler üzerindeki etkilerinden daha çok faydalanma yoluna gidildi. Atatürk'ün cumhurbaşkanlığı döneminde sinemadan faydalanma konusunda gösterilen bu çabanın amacı niteliği ve yansımaları araştırmanın konusunu oluşturmaktadır. Araştırma yapılırken; önce Türkiye'deki sinema alt yapısına değinilmiş, daha sonra sinemanın gelişimi konusundaki bu ilk süreç Atatürk'ün ve Cumhuriyet Halk Partisi'nin konuya yaklaşımı da göz önünde bulundurularak analiz edilmeye çalışılmıştır.
\end{abstract}

Anahtar Kelimeler: Atatürk, Cumhuriyet Halk Partisi, Propaganda, Sinema, Film

\section{ABSTRACT}

Cinema which entered Turkey in the last period of the Ottoman Empire experienced some of its preliminaries until the Republic of Turkey was declared. The propaganda power of cinema had been noticed from the First World War. After long years of war when the Republic had been proclaimed in Turkey, cinema had an embryonic heritage. However, in the early years of the Republic, there was a heightened awareness of the propaganda properties and inspirational power of the cinema. Economic and technical limitations made it possible to benefit from cinema only to a certain extent. But as these initial limitations waned, the Republic started to build the infrastructure of cinema in Turkey from the 1930s. While cinema legislation was formed in this period, it aimed to benefit 
more from the effects of cinema on the masses. The purpose, the quality, and the reflections of this effort which brought about the benefit from cinema in Ataturk's Presidency period, is the goal of this research. While research has been conducted previously, it primarily referred to the cinema infrastructure in Turkey. Later research focused on the impact that Ataturk and the Rebublican People's Party had on the development process of cinema in Turkey.

Keywords: Ataturk, Republican Party, Propaganda, Cinema, Film

\section{Extended Abstract}

Cinema is considered an effective propaganda tool during times of war and peace. The use of cinema for propaganda became known at the beginning of the 20th century in Turkey. There was also an awareness of this tool during the Ottoman period. Upon the request of Enver Pasha, the Central Army Cinema Department was established in 1915 for the use of cinema for propaganda in the Ottoman Army. So, experience was gained from previous history.

When the Republic was declared, it was decided that cinema should be used for propaganda and indoctrination. Because Turkey had been affected by the inter-war period, propaganda was used effectively to create a new world order. Among the main goals were the introduction of the new state inside and outside the country, the adoption of the new regime by the people, and the creation of the type of people that the new regime envisioned.

The developments regarding propaganda in the field of cinema during Atatürk's Presidency form the subject of this study. The significant strides made in this area and their reflections on socio-economic and political spheres were addressed within the scope of the study. Documents in the Presidency of State Archives, the minutes of Grand National Assembly of Turkey, and other published materials were used for research and analysis. These documents proved important in terms of revealing the state's approach to the issue.

The Republican People's Party, which ruled the country, did not completely ignore the use of cinema for propaganda in the 1920s. However, as the party's rule matured conditions changed, and more comprehensive and targeted studies were carried out in the early 1930s. As a result of these studies, a report was prepared by the party through the responsible bodies and it provided important data about the use of cinema for propaganda purposes in Turkey during this period. The report included detailed information such as comparative data about the cinema, the effects of cinema on the public, a project that could be carried out for dissemination of propaganda and the cost of this. It is noteworthy that providing alternative solutions for the financial burden of cinema 
production was a condition in those days. Turkey was influenced by the example of Soviet Russia, where good relations had developed during the Armistice years, in using cinema propaganda in educating the people.

Of course, during this period the lack of technical and economic opportunities was an obstacle in popularizing cinema. However, the lack of the cinema for propaganda and indoctrination purposes did not discourage Atatürk and the Party. Atatürk showed an interest in the subject of cinema, watched various movies from time to time, was involved in the filmmaking process with his image, criticized the films he watched, and gave instructions for making certain films.

Some of the films which have propaganda features of this period were Shirt of Fire (1923), Ankara Post (1929), A Nation Awakes (1932), Ankara, the Heart of Turkey (1934), Aysel, the Girl From the Swampy Roof(1935), and Forward Steps in the Turkish Revolution (1937).

After the first experiences of the 1920s in the field of cinema, one of the most significant developments in the 1930s was the formation of cinema legislation because cinema had become a sector that needed regulation. Therefore, the formation of legislation was studied in detail in the study. Cinema was an important tool even in printed media, which could be used for the party and thereby the state. The need for cinema to establish the national economy in general and to increase exports in particular was observed during the examination of the legislation studies. In explanations in the minutes of the Turkish parliament neither the Soviets nor Turkey were unique in the ability to benefit from using cinema for educating the public about economic developments. Generally, it was the chosen way of reducing the high tax rates that were contributed to public education and instruction by popularizing the cinema during legislative making. Since cinema should not pose a danger to the state or regime, the first censorship law was enacted to prevent the emergence of any undesirable effects of cinema during those years.

Thus, these developments in Ataturk's period were a formation process that prepared the infrastructure of cinema in all aspects after a preparatory period in Turkey. This process, which was created by making use of world experience, is a reservoir that will constitute a resource for later periods. 


\section{Giriş}

Propaganda genel bir ifadeyle; bir öğreti, düşünce veya inancı başkalarına tanıtmak, benimsetmek ve yaymak amacıyla söz, yazı vb. yollarla gerçekleştirilen çalışma, yaymaca olarak tanımlanmaktadır. ${ }^{1}$ Kitlelere yönelik bir dil olan propagandada; basın, radyo, sinema gibi araçlarla kitlelere ulaştırılan çeşitli simgeler kullanır. Propagandacının amacı, propagandanın kapsamına alınan konularda kitlelerin tutumunu etkilemektir. Sinema, belgesel değeri için kullanılsa da tiyatro gibi eski bir efsaneden, tarihsel bir konudan veya çağdaş bir senaryodan yararlanarak bazı görüşleri yaymak için kullanılsa da etkili bir propaganda aracıdır. ${ }^{2}$

Sinema, savaş ve barış zamanlarında sadece siyasi alanda değil; ticaret, din, ırk, eğitim gibi konularda da propaganda aracı olduğunu gösterdi. Birinci Dünya Savaşı esnasında Amerikan filmleri, Amerika'da ve başka ülkelerde propaganda için kullanıldı. Hollywood'un, resmî propaganda ve sansür dairesi olan Committe of Public Information adlı kurumun yönetiminde yaptığı filmler, Almanya aleyhine bir nutkun, kitabın veya gazetenin yapamayacağını yaptı. ${ }^{3}$

Fakat sinemanın halk kitleleri üzerine yaptığı etki, barış zamanında savaş zamanındakinden daha önemliydi. Barış zamanındaki filmin etkisi siyasi otoriteleri, propagandacıları, hatta eğitimden sorumlu yetkilileri birçok önemli konuyla karşılaştırdı. Batı ülkelerinde, gazete gibi sinema da halkın günlük hayatta siyaset, iktisat, din ve irkla ilgili konulardaki görüşlerini etkilemekle kalmadı, sosyal kurum ve kuruluşları korumakla yükümlü olan birçok kişiyi endişelendiren büyük değişiklikler meydana getirdi. Bu yüzden sadece ticari amaçlarla başlayarak gelişen ve oldukça büyük bir ticaret ve sanayi kolu haline gelen filmin başka amaçlarla kullanılabileceği fark edildi ve bu konuda birçok tecrübe yaşandı. ${ }^{4}$

Propagandayı etkili kullanmak konusunda akla gelen iki önemli liderden biri olan Lenin, Bolşevizmi büyük ölçüde propaganda ile yerleştirirken; Hitler, iktidarı ele geçirmesinden 1940'a kadar bütün zaferlerini propaganda sayesinde kazand1. Lenin "Önemli olan bütün toplum katmanlarında kargaşa çıkarmak, propaganda yapmaktır.” derken; Hitler, "Propaganda iktidarı elde tutmamızı sağladı, dünyayı fethetme olană̆ını da bize yine propaganda verecek." diyordu. ${ }^{5}$

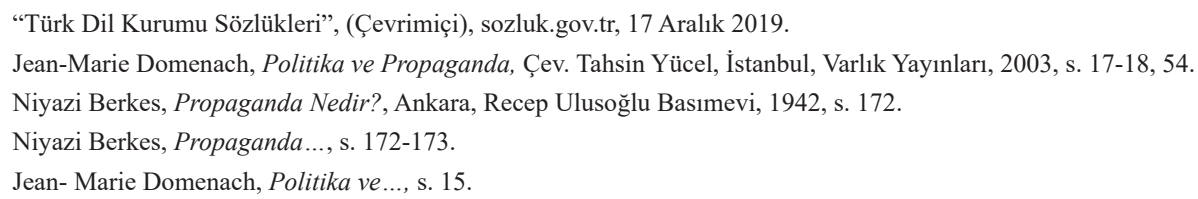


Bolşevik rejimde Troçki ve Lunaçarski, sinemanın propaganda silahı olarak etkisini iyi saptamışlardı. 1918'de bizzat Lunaçarski, aydın burjuva ile işçi sınıfı arasındaki yakınlaşmanın zorunluluğunu gösteren bir film yaptı. Bununla birlikte, entelektüel Bolşeviklerin görüntüden çok konuşma ve metin çözümleyicileri olarak birer papaz gibi davrandıklarından söz ediliyordu. Aslında sinema gerçek anlamıyla Bolşeviklerin uğraş alanı içine girmiyor, eğitici filmler yapılmasından yana olan Lenin'in zihninde sınırlı bir yer işgal ediyordu. Bolşevikler, film üretimini ancak 1927-1928'e doğru Stalin'in, Troçki'nin isteğini gerçekleştirmesiyle sahiplenmişlerdi. Hatta Pravda'nın sinemayı ele alan ilk başyazısı 1934'te Çapaev'in gösterime girmesi üzerineydi. Film bir propaganda aracı olduğu kadar bir saygınlık nesnesi haline gelmeye başlamıştı. ${ }^{6}$

Naziler için ise sinema, iktidarı ele geçirmelerinden sonra yalnızca bir propaganda aracı olmad1. Aynı zamanda bir enformasyon aracı haline geldi ve Nazileri paralel bir kültürle donattı. Goebbels ve Hitler'in bütün günlerini sinemada geçirdikleri oluyordu. Goebbels, Lunaçarski gibi senaryoculukla yetinmedi, bir filmin yapımının bütün aşamalarında aktif rol aldi. ${ }^{7}$

\section{Sinemanın Türkiye'ye Girişi}

1895 yılında Lumiéré kardeşlerin operatörleri, çekim çalışmaları yapmak üzere çeşitli ülkelere gitmişlerdi. Bu operatörlerden Türkiye'ye gelen Promio, İstanbul ve İzmir dolaylarında kısa filmler çekmişti. Halka açık ilk film gösterisi ise 1896-1897 yıllarında Sigmund Weinberg tarafından Sponek denilen yerde gerçekleştirildi. Türkiye'de ilk yerleşik sinema salonunu açan da yine 1908'de Weinberg oldu. Pathé adlı Fransız film kumpanyasının Türkiye'deki ilk temsilcisi olan Weinberg'in kurduğu Pathé Sineması'nı daha sonra halka açılan diğer sinemalar izledi. 1910 yılında sinemanın okullarda kullanımı İstanbul Sultanisi'nde dâhiliye şefi olan Fuat Uzkınay sayesinde oldu. Fuat Bey, Pathé Sinemasın'ın makinistinden film göstermeyi öğrenmiş, sonra okulun müdürü Ebülmuhsin Bey’i teşvik ederek okulda film gösterilmesini sağlamışt1 ${ }^{8}$

Daha XIX. yüzyılın sonlarından itibaren, kişileri ve olayları, özellikle de hükümdar ailelerini ilgilendiren gelişmeleri filme alan kameralar bulunmaktaydı. XX. yüzyılın

\footnotetext{
Marc Ferro, Sinema ve Tarih, Türkçesi: Turhan Ilgaz-Hülya Tufan, İstanbul, Kesit Yayıncılık, 1995, s. 55.

Marc Ferro, Sinema ve..., s. 56.

Zahir Güvemli Sinema Tarihi, İstanbul, Varlık Yayınevi, 1960, s. 231; Agah Özgüç, Başlangıcından Bugüne Türk Sinemasında IIlkler, İstanbul, Yılmaz Yayınları, 1990, s. 7-10.
} 
başında ise kamera ilk siyasal eylemi yakalamış ve film siyasal amaçlarla kullanılmaya başlanmıştı. Propaganda türünden böyle filmler, 1914-1918 yıllarındaki savaşla beraber, ordularda görevli film çekme birimlerinin de etkisiyle çoğaldı. ${ }^{9}$

Osmanlı Devleti'nde ise 1914 yılında İtilaf Devletleri'ne karşı savaşa girilmesiyle, Ayestefanos'ta dikili, 1877-1878 Türk-Rus Savaşı'nın izlerini taşıyan anıt bombalandı ve bu olay Fuat Uzkınay tarafindan kameraya alınarak 14 Kasım 1914 günü Ayastefanos 'taki Rus Abidesi'nin Yıkılışı adıyla sinema tarihine geçen ilk belge filmi gerçekleşti. ${ }^{10}$

Birinci Dünya Savaşı sırasında Almanya'ya seyahat eden Başkumandan Vekili ve Harbiye Nazırı Enver Paşa Alman ordusunda bulunan sinema kolunun savaşla ilgili belge filmleri çektiğini, savaş propagandası yaptığını ve askerlerin eğitiminde faydalanıldığını görmüştü. Enver Paşa'nın Osmanlı ordusunda da propaganda konusunda çalışacak böyle bir kolun kurulmasını emretmesi üzerine 1915 yılında Merkez Ordu Sinema Dairesi (MOSD) kuruldu. Faaliyeti 1918 yılında sona eren MOSD, bu süre içinde belge filmi alanında pek çok film çekti. ${ }^{11}$ Bu yıllarda Merkez Ordu Sinema Dairesi'nden başka Müdafaa-i Millîye Cemiyeti'nin de bir stüdyosu vardı. Bazı savaş sahneleri, Boğaziçi'nden sahneler ve daha sonra konulu film çekme girişimleri bu cemiyet aracılığıyla gerçekleştirildi. Mütareke ilan edilince Ordu Film Merkezi ortadan kalktı ve donanımı Malul Gaziler Cemiyeti'ne (MGC) devredildi. Malul Gaziler Cemiyeti, sinema çalışmalarına 1919 yılında başlayarak, İzmir'in işgali üzerine İstanbul'da yapılan mitingi filme ald $1^{12}$

1920-1921 yıllarında belge filmi adına kayda değer bir çalışma olmadı. 1922 yılında Başkumandanlık Meydan Muharebesi filme alındı. Ordunun İzmir'e gelişi sırasında yapılan çalışmalar da önemlidir. TBMM Ordu Film Çekme Merkezi ile Kemal Film ekibinin çalışmaları sonucu elde edilen film parçaları daha sonraki yıllarda kullanıldığı gibi, kurgu filmleri için de kaynak oldu. 1922 yılının belge filmleri alanında en önemli çalışması Fuat Uzkınay tarafindan Kemal Film adına yapılan Zafer Yollarında adlı belge filmiydi. Ordu Foto Film Merkezi elemanları da İzmir Zaferi, Dumlupınar Vekayii, İzmir Nasıl İstirdad Edildi, İzmir 'in İşgali, İzmir'deki Yunan Fecayii, İzmir Yanıyor, Gazi'nin İzmir'e Gelişi ve Karşılanışı gibi bazı kısa filmleri çekti. Cezmi Ar tarafindan çekilen İşgal Ordularının Ístanbul'u Terki adlı belge filmi savaşla ilgili çekilen son film olarak nitelendi. ${ }^{13}$

\footnotetext{
9 Marc Ferro, Sinema ve..., s. 54.

10 Alim Şerif Onaran, Türk Sineması, C. 1, Kitle Yayınları, s. 12-13; Rekin Teksoy, Rekin Teksoy’un Sinema Tarihi, C. 1, İstanbul, Oğlak Yayıncılık, 2009, s. 66-67.

11 Erman Şener, Kurtuluş Savaşı ve Sinemamız, Dizi Yayınları, 1970, s. 12-17.

12 Zahir Güvemli, Sinema ..., s. 232-234; Erman Şener, Kurtuluş Savaşı..., s. 18-19; Alim Şerif Onaran, Türk..., s. 12-13.

13 Erman Şener, Kurtuluş Savaşı... s. 22-28.
} 
1919 yılında savaş devam ederken ticari amaçlı ilk Türk film şirketini kuran Kemal ve Şakir kardeşler, başlangıçta sadece işletmecilik yaparken 1922'de bir stüdyo kurmuş, Kemal Film adıyla yapımcılığa geçerek rejisörlüğe Muhsin Ertuğrul'u getirmişti. ${ }^{14}$ Yeni kurulan bu şirketin, konulu filmler yanında asıl önemli çalışması haber filmi alanında yaptığ 47 adet filmdir. Bu filmlerin içinde Gazi Mustafa Kemal Paşa'nın İzmit Cephesi'ni Teftişi adlı film önemlidir. ${ }^{15}$

\section{Cumhuriyeti'n İlk Filmlerinde Propaganda ve Telkin}

Türkiye'nin sinema yolculuğu Osmanlı'nın son dönemleri ve savaş yıllarındaki bu deneyimlerle Cumhuriyet'in ilanına kadar geldi. Cumhuriyet'in ilanı ile başlayan dönemde ise halka gösterilmesi istenen filmler genel olarak eğitsel nitelikli belgesel veya aktüalite filmleri idi.

Cumhuriyet'in ilan edildiği yıl olan 1923, 1914'te başlayan filmcilik anlayışının adeta bir devamı niteliğinde, sinema açısından uzun ve kısa belge filmlerinin çekildiği, günlük olaylardan yararlanıldı̆̆ bir yıl oldu. Ístanbul'un Itilaf Devletleri Tarafindan Tahliyesi, İstanbul'a Ordunun Gelişi gibi filmler 1923 yapımıydı. ${ }^{16}$

Belge filmi niteliğinde olmayan 1923 yapımı Ateşten Gömlek; Muhsin Ertuğrul'un sinema kariyerinde Türkiye Cumhuriyeti'nin ilan edildiği yıl yapılan ilk film ve Türk kadınının rol almasına izin verilen ilk film olma özelliğini taşımaktadır. Ertuğrul'un Kemal Film adına çevirdiği filmler içinde en önemlisi olan bu film, ulusal duyguların yoğun yaşandığı bir zamana rastlamasından dolayı iyi karşılandı. Ertuğrul, ulusal bir konusu olan bu filmin kadın kahramanlarını Bedia Muvahhit ve Neyyire (Münire) Neyir adlı Türk oyuncuların canlandırması için çabaladı. ${ }^{17}$

Sovyetler Birliği'nden Türkiye'ye dönen Ertuğrul, 1928 yılında Ankara Postası adlı filmi yapmaya başladı. Bu film ertesi yıl tamamlandı. Ertuğrul'un Kurtuluş Savaşı'nı canlandırmak için kullandığı eser François de Curel'in Alman Fransız çatışmasına dayanan La terre inhumanie adlı oyunuydu. Reşat Nuri Güntekin, bu oyunu Bir Gece Faciası adıyla Kurtuluş Savaşı'na uygulamıştı. ${ }^{18} 1929$ yılında gösterilen film, Millî Mücadele yıllarında işgal altındaki Anadolu'da Adapazarı'nda Kuvayi İnzibatiye mensupları ile vatanın kurtarılmasına çalışan Türkler arasında geçen bir olayı konu almıştı. Filmin bazı

14 Zahir Güvemli, Sinema ..., s. 235-236.

15 Erman Şener, Kurtuluş Savaşı... s. 23.

16 Nijat Özön, Türk Sineması Kronolojisi, Ankara, Bilgi Yayınevi, 1968, s. 57.

17 Nijat Özön, Türk Sineması Tarihi, İstanbul, Ekicigil Matbaası, 1962, s. 78-79; Agah Özgüç, Başlangıcından Bugüne..., s. 38.

18 Nijat Özön, Türk Sineması Tarihi, s. 91-92. 
eksikleri olmasına rağmen perde karşısına ilk defa geçen sanatçıların başarısı ümit verici bulundu. Vakit gazetesinin haberine göre; daha önce birkaç film yapımı denenmiş olsa da bu yeni sanat ve sanayi dalının gelişmesine iktisadi buhran izin vermedi. ${ }^{19}$ Aynı yıl bir belge filmi için CHP tarafından gönderilen yazıya göre; Gazi’nin işlenmemiş haliyle satın aldığı çiftliğin hangi aşamalardan geçerek mamur hale getirildiğinin, nüfusunun çoğunluğu çiftçi olan halka sağlayacağı fayda düşünülerek gösterilmesi isteniyordu. ${ }^{20}$

1931 yılında yabancı filmlere yerli sahneler eklemek suretiyle yerlileştirme denemesi gerçekleştirildi ve Çanakkale Geçilmez adlı film yapıldı. Filmin yapımı için Anthony Asquith'in Tell England (1930) filmine yerli sahneler eklenmişti. ${ }^{21}$

1932 y1lında çevrilen Bir Millet Uyanıyor adlı film, Muhsin Ertuğrul'un Kurtuluş Savaşı konulu en iyi filmi ve Türk sinema tarihindeki ilk başarılı filmlerden biri olarak tanımland1. Filmin senaryosu, Nizamettin Nazif tarafından yazılan orijinal film hikâyesine dayanıyordu. ${ }^{22}$ Film 1918 yılında Mondros Mütarekesi'nin imzalandığı tarihten başlayarak İzmir'in işgali, Atatürk'ün Samsun'dan Erzurum'a gitmesi, Erzurum ve Sivas kongreleri, Atatürk'ün Ankara'ya gelmesi, Mebusan Meclisi’nin açılışı gibi Kurtuluş Savaşı'na ait pek çok gelişmeyi içeriyordu. ${ }^{23}$ Atatürk, bu filmin senaryosunu incelemiş ve filmin bir bölümünde kullanılmak üzere kendi görüntüsünün çekilmesine onay vermiş, siyah bir perde önünde dünya ve ülke sorunlarıyla ilgili bir konuşma yapmıştı. ${ }^{24}$

1934 yılında Halil Kamil (HA-KA) Türk Inkılabında Terakki Hamleleri adlı uzun belge filmini hazırlatmaya başladı. Filmin çekimleri 1937 yılında tamamlandı. 1934 yılında ayrıca, Sovyet yönetmenler Sergey Yutkeviç ve Lev Arnştam Cumhuriyet'in 10. yıldönümü için hazırladıkları Ankara Türkiye'nin Kalbidir adlı belge filmini tamamlad1. ${ }^{25} \mathrm{Bu}$ film 1970 y1lında Ankara'da televizyonda gösterilirken, Rus heyetinin ekranda fazla yer aldığının düşünülmesi üzerine yasaklanacaktır. ${ }^{26}$

1922 yılında yapımına başlanan Zafer Yollarında adlı film ilk şekliyle Uzkınay’ın kendi çektiği belge filmlerinden meydana getirdiği bir kurgu filmiydi. Zaferden sonra

19 "Yerli Film Ankara Postası Dün İlk Olarak Davetlilere Gösterildi”, Vakit, 30 Eylül 1929, s. 2.

20 Türkiye Cumhuriyeti Cumhurbaşkanlı̆̆ Devlet Arşsivleri Başkanlı̆̆ Cumhuriyet Arşivi (BCA), 490100/139 (Gazi hazretlerinin çiftliklerinin durumunu gösteren film ile ilgili 06/10/1929 tarihli yazı).

21 Nijat Özön, Türk Sineması Kronolojisi, s. 66.

22 Nijat Özön, Türk Sineması Tarihi, s. 96.

23 Nizamettin Nazif Tepedenlioğlu, Bir Millet Uyanıyor, İstanbul, Kanaat Kütüphanesi, 1933(?), s. 5-34.

24 Atilla Dorsay, Sinema ve Çă̆ımız, İstanbul, Remzi Kitabevi, 1998, s. 16.

25 Nijat Özön, Türk Sineması Kronolojisi, s. 70-71,74.

26 Erman Şener, Kurtuluş Savaşı... s. 33. 
Uzkınay, Film Çekme Merkezi Laboratuvar Grup Amirliği'ne atanınca filmi genişletme çalışmalarına başlandı. Dumlupınar Vekayii, İzmir Istirdadı, Gazi'nin İzmir'e Gelişi ve Karşılanışı gibi parça filmlerle genişletilen film, 1930'dan sonra daha da zenginleşti. Filmi 1934 y1lında tekrar izleyen Atatürk'ün 3 bölümden ibaret filmi tatminkâr bulmaması üzerine, filmin genişletilmesi için bir heyet kurularak çalışmalara başlandı ve film 12 bölüme çıkarıldı. 1937 yılında Atatürk, filmin tamamlanıp tamamlanmadığını sorduğunda, kendisine ait sahnelerin çoğunun hareketsiz resimlerden ibaret olması nedeniyle tamamlanamadığını öğrendi. Bunun üzerine Atatürk’ün böyle bir teklifi memnuniyetle kabul edeceğini, filmde rol alarak hatıraları canlandıracağını söylediği belirtilmektedir. Çünkü Türk gençliğine bu mücadelenin nasıl kazanıldığını göstermek, hatıra bırakmak bu filmle mümkün olacaktı. ${ }^{27}$

Sovyet köy filmlerine öykünme, yabanc1 film aktarması gibi eğilimlerin görüldüğü 1935 yılında, 1934 yılında çevrilmeye başlanan Aysel, Bataklı Damın Kızı adlı film tamamlandı. Filmin tanıtım yazısından, hikâyenin Hasan Cemil (Çambel) tarafından yazıldığı anlaşılmıştır. Ama Özön'ün belirttiğine göre aslında Selma Lagerlöf'ün Tösen fran stormytorpet adlı öyküsünden alınmıştır. Filmin konusu o zamana kadar çevrilen filmlerden farklı olup, şehrin ve şehirlilerin dar yaşayışlarını değil, köylünün yaşantısını konu edinmişti. Özön'ün ifadesiyle Ertuğrul'un Türk sinemasına ilk kırsal dramasını sunduğu bu film, Sovyet sinemasından izler taşımaktaydı. ${ }^{28}$

Bu dönemde Atatürk’ün de sinemayla yakından ilgilendiğini görüyoruz. Yerli ve yabancı bazı filmleri Elhamra, Opera, Glorya gibi sinemalarda izleyerek yerinde tetkik ettiğini, sinemanın insanlar üzerinde bırakacağı muhtemel etkileri görerek bizzat film çekilmesini sağlamak için girişimde bulunduğunu görmekteyiz. ${ }^{29}$ Cemal Granda'nın anılarında belirttiğine göre Atatürk'ün izlediği ilk Türk filmi, Türk filmciliğinin yeni parlamaya başladığı yıllarda gösterime giren Muhsin Ertuğrul'un İstanbul Sokaklarında adli filmiydi. ${ }^{30}$

Ocak 1932'de İstanbul'da Opera Sineması'nda film izleyen Atatürk'ün dikkatini çeken bu film, Çanakkale Harbi adlı filmdi. Cemil Filmer'in aktardığına göre İngilizler filmde tarafgir davranmamışlar, hakikati olduğu gibi göstermişlerdi. Türk ordusunun Çanakkale'de gösterdiği kahramanlık, filme olduğu gibi yansımıştı. Yanında Maliye

27 Erman Şener, Kurtuluş Savaşı... s. 31-32; Atilla Dorsay, Sinema ve..., s. 16.

28 Nijat Özön, Türk Sineması Tarihi, s. 100-101.

29 “Gazi Hazretleri Dün Elhamra Sinemasına Giderek Bazı Filmleri Temaşa Ettiler”, Akşam, 5 Kanunievvel 1930, s. 1-2; Giovanni Scognamillo, Cadde-i Kebir'de Sinema, İstanbul, Metis Yayınları, 1991, s. 35-41.

30 Turhan Gürkan, Atatürk'ün Uşağının Gizli Defteri, İstanbul, Fer Yayınları, 1971, s. 134. 
Bakanı Fuat Ağralı ile filmi görmeye gelen Atatürk'e burada sinema ücretlerinden bahsedilmiş, Atatürk de sinemanın çok faydalı bir icat olduğunu, halkın bundan gerektiği gibi faydalanmasını, sinemacılığın gelişmesini, bu nedenle de alınan vergilerin düşürülmesini istemişti. Filmer'in anılarında aktardığına göre Ankara’ya döndükten bir süre sonra gerçekten de alınan vergiler \%10'a indirilmişti. ${ }^{31}$

Ayrıca Atatürk'ün bu yıllarda bir filmin yapılması için bir direktif verdiği TBMM antetli bir belgeden anlaşılmaktadır. Bu direktifte Münir Hayri’nin film çevirme işi ile bizzat meşgul olacağı, hemen Almanya’ya giderek senaryoyu işleyeceği, Hasan Rıza'nın gereken masrafları kendisinden karşılayacağı belirtilmektedir. ${ }^{32}$ Münir Hayri Egeli de anılarında, bu fillmle ilgili olduğunu düşündürecek şekilde, Atatürk’ün kendi hayatına dair bir film yaptırmaya karar verdiğinden, filmin esaslarını kendisine dikte ettirdikten sonra iki defa tashih ettiğinden söz etmektedir. ${ }^{33}$

1937 yılında sinema dişından bir isim olarak Nazım Hikmet Ran'ın da bu türden bir film denemesi olmuştu. Güneşe Doğru adını taşıyan filmin rejisörü, Ertuğrul'un yanında senaryoculuk, rejisör yardımcılı̆̆ı yapan Ran'dı. Filmin konusu Mütareke Dönemi’nde hafızasını kaybeden bir gencin, 17 yıl boyunca kendisini hep o yıllarda yaşıyor sandıktan sonra iyileşmesi ve kendisini Cumhuriyet Türkiyesi'nde bulmasıydı. ${ }^{34}$

\section{Cumhuriyet Halk Partisi ve Bir Sinema Raporu}

Propagandanın devletlerin iç ve diş politikalarını gerçekleştirmek amacıyla yaygın olarak kullanıldığı iki savaş arası dünya düzeninde, Cumhuriyet'in ilk hükümetleri de sinemayı propaganda yapmak ve halkı eğitmek amacıyla kullanmak istemişlerdi. Bununla beraber 1930'ların sonuna yaklaşırken Cumhuriyet Halk Partisi (CHP) Genel Sekreterliği tarafından yapılan bir araştırma sonucu hazırlanan rapor, dönemin sinema ile ilgili gelişmelerinin istenen durumda olmadığını gözler önüne sermektedir. Rapor, iktidarın sinemaya yaklaşımını ve sinemayı rejim lehine kullanabilmek için ayrıntılı önerileri içermesi bakımından önemli bulunmuştur.

31 "Reisicumhur Hazretleri Sinemada", Hakimiyet-i Millîye, 24 İkincikanun, 1932, s. 1; Cemil Filmer, Hatıralar, İstanbul, Emek Matbaacılık ve İlancılık, 1984, s. 149-150.

32 Söz konusu filmin "Ben Bir İnkılap Çocuğuyum” adlı film olduğu düşünülmektedir. Mustafa Kemal Atatürk, Atatürk'e Ait Bir Direktif, 1936(?).

33 Münir Hayri Egeli, Atatürk'ün Bilinmeyen Hatıraları, İstanbul, Yenilik Basımevi, 1954, s. 20.

34 Nijat Özön, Türk Sineması Tarihi, s. 102-103; Burçak Evren, 100 Years Of Turkish Cinema, Ankara, T.C. Kültür Bakanlığı Yayınları, 2014, s. 97. 
Atatürk döneminde CHP Genel Sekreterliği VIII. Büro'nun görevi propaganda ve duyuktu. Propaganda sinema, radyo ve basin kanaliyla yapılacaktı. CHP Genel Sekreterliği, halkevleri ve parti teşkilatının radyo ve sinemadan faydalanması konusunu ilk defa 1932 yılı sonlarında incelemeye başlamış ve bu inceleme sonunda Genel Yönetim Kurulu tarafından 27 Şubat 1933 tarihli toplantıda bazı kararlar verilmişti. Alınan kararlara istinaden bazı halkevi ve parti salonlarının sesli gösterici sinema makineleriyle, hiç sineması olmayan bazı yerlerin de sessiz sinema gösterici makineleriyle donatılması ve bu konuda araştırma yapılması ilgili bürolara havale edilmişse de 1936 yılı başına kadar bu alanda hiçbir çalışma yapılmamıştı. ${ }^{35}$

CHP'nin 1936 yılındaki bu raporu hazırlanmadan hemen önce, aynı yılın ocak ayında CHP Genel Sekreteri tarafından Halkevi Başkanlığı'na bir yazı gönderildi. Halkevlerinde sinema olup olmadığı, kim tarafından ve ne suretle işletildiği, sinemadan ne suretle faydalanıldı ğı, hangi filmlerin kaç gün aralıklarla gösterildiği, bu filmlerin nasıl tedarik edildiği gibi sorularla durum tespiti yapılmak isteniyordu. ${ }^{36}$

Genel Yönetim Kurulu 27 Şubat 1936 tarihinde yeniden toplandığında, büyük stüdyo ve senaryo işleri partinin gücü dişında görülüyordu. Partinin istediği şekilde propaganda ve kültür fillmleri yaptırmak için var olan kuruluşlarla temasa geçilmesi; siyasî, ziraî ve kültür fillmleri yapan, satan ve kiralayan kuruluşlarla temasa geçilerek faydalı filmlerin gösterilmesi için hazırlanması konusunda karar alındı. Planlanan bu film gösterimlerinin yapılabilmesi için halkevlerinin projeksiyon (sinema) makineleri ile donatılmas1, elektrik olmayan yerlerde ise sinema göstermeye uygun portatif sinema makinesinin satın alınması hususunda karar verildi. Halkevlerinde projeksiyon makinesi alınması için etüt yapılacak, bu işlerin takibinden CHP VIII. Büro sorumlu olacaktı. VIII. Büro, bu işi başarmak üzere teknik bir komisyon oluşturdu ve bu işlerin tetkikini bu komisyona havale etti. ${ }^{37}$

Alınan bu karar ile ilgili olarak 25/08/1936 tarihinde CHP Genel Sekreterliği tarafindan yayınlanan bir tamimle parti tarafından toptan bir miktar seyyar sesli sinema makinesi alınacağı, ülkenin ihtiyacına en uygun makineyi seçmek için oluşturulan komisyonun karara varmasından önce satın alma yapılmaması istenecekti. Komisyonun tespit

$35 B C A, 490100 / 1221562$ (Parti propagandası için kullanılacak sinema üzerine yazılmış yazılar ve CHP’nin 27/02/1936 tarihli raporu).

$36 B C A, 490100 / 3121$ (Halkevlerinde radyo, sinema ve toplantı salonları ile ilgili 03/01/1936 tarihli yazı).

$37 B C A, 490100 / 1221562$ (Parti propagandası için kullanılacak sinema üzerine yazılmış yazılar ve CHP'nin 27/02/1936 tarihli raporu). 
edeceği tip belirlendikten sonra sadece belirtilen tipte makineler alınacaktı. ${ }^{38}$ Birkaç aylık inceleme ve tecrübenin ardından, komisyon tarafindan elde edilen sonuç, Şubat 1937 başlarında bir rapor halinde Genel Sekreter'e ve ardından incelenmek üzere Nafia Vekâleti'ne gönderilecekti. ${ }^{39}$

CHP VIII. Büro'nun birçok bakımdan kayda değer bu raporunda uzun zaman ciddiye alınmayan; aşağı tabakaya mahsus, kıymetsiz bir eğlence vasıtası olarak kabul edilen sinemanın etkileri itibariyle matbaacılıktan daha önemli bir keşif olduğu belirtiliyordu. 1935 yılının sonlarında dünyada toplam 62.000 sinema salonu vardı. Sovyet Rusya, Fransa, Almanya, İngiltere ve Türkiye'nin 1933 yılına ait sesli ve sessiz sinema sayıları karşılaştırıldığında, en az sinemaya sahip ülke Türkiye idi. Sinemanın uyandırdığı genel ilgi hakkında bir fikir edinilmesi için sadece Fransa'da, Paris hariç, bir haftada 5.000.000 kişinin sinemalara gittiği belirtilmekteydi. Diğer temsil araçlarına göre çok önemli bir yer tutan sinemalar herkesin devam ettiği bir tür gece okulları halini almıştı. ${ }^{40}$

Söz konusu rapora göre sinema gerçek hayatı andıran bir dünya yaratmak konusunda başarılıydı. İnsanlar sinemada gördüklerine önem veriyorlardı ve gördüklerini benimsemeye meyilliydiler. Böylece toplumun dörtte üçü isteyerek veya istemeyerek sinemanın etkisinde kalıyordu. Özellikle ortalama kadın seyirci, sinema salonlarında davranış, görgü ve nezaket kuralları dersleri almaktaydı. Bu insanların günlük hayatta özellikle tereddütlü oldukları durumlarda hareket tarzlarını belirlemede sinemada gördükleri sahneler etkili olmuştu. İnsanlar sinemanın yarattığı dünyaya benzemeye çalışıyordu. Bu nedenle film, en etkili millî propaganda aracı olmuştu. Adetler ve politika alanında, sanayi-i nefise alanında, toplumsal konular gibi pek çok alanda iyi yönetilen bir sinema mücadelesi, barışçı bir etkileme yöntemi olmaktaydı. Bu şekilde bir mücadele, pedagojik ve kesin hükümlerle asla uygulanamazdı. Propaganda ifadesi kullanıldığı takdirde filmin etkisi aşağı yukarı sıfırlanacaktı. ${ }^{41}$

Özellikle halkın bilinçlenmesi ve eğitilmesi konularında Sovyet sinemacılığı örneği, kapitalizmin kanunlarına tabi olmayan yegâne sinemacılık numunesi olarak görüldü. Millî sanayi, öğretim ve propaganda aracı olan Sovyet ürünleri kapitalist devletlerin ürünleri ile karşılaştırılamazdı. Bazı filmlerin yapılmasında özellikle Almanya'da devletin büyük

$38 B C A, 490100 / 31317$ (CHP'nin tespit edeceği sinema makinelerinden alınması ile ilgili 25/08/1936 tarihli yazı).

$39 B C A, 490100 / 1221562$ (Parti propagandası için kullanılacak sinema üzerine yazılmış yazılar ve CHP'nin 27/02/1936 tarihli raporu).

$40 B C A, 490100 / 1221562$ (Parti propagandası için kullanılacak sinema üzerine yazılmış yazılar ve CHP'nin 27/02/1936 tarihli raporu).

$41 B C A, 490100 / 1221562$ (Parti propagandası için kullanılacak sinema üzerine yazılmış yazılar ve CHP'nin 27/02/1936 tarihli raporu). 
nakdi yardımları olmuşsa da Rusya'dan başka hiçbir yerde devlet sineması yoktu. Sovyetler'den başka bütün ülkelerde sinemacılık özel sermayenin elindeydi. ${ }^{42}$

Raporda Memleket Içinde ve Dışında Sinema ile Yapılacak Propaganda Projesi hakkında da bilgi veriliyordu. Proje kapsamında yapılacak başlıca iş, fillmi araştırıp bulmak ve filmin ülkenin her yerinde gösterilmesini sağlamaktı. Filmleri araştırıp bulmak aşamasında, Türkiye'deki prensiplere benzer prensipleri yaymak amacıyla yurt dişında yapılan filmleri kiralayıp göstermek, yöntemlerden biriydi. Bu suretle gösterilecek filmler iki kısma ayrılmıştı:

Birinci kısımda yer alan filmler:

- Artistik, sosyal değeri olan dram, komedi, operet ve saire gibi büyük eserlerdi. Bunlar kültür seviyesi yüksek olan halk tabakasına özgü olacaktı. Bu tür filmlerle yapılacak propaganda, seyircilerin üstünde bir propaganda filmi etkisi yapmayacak kadar ince işlenmiş olmalıydı.

İkinci kısımda yer alan filmler:

- Köylüler için filmler, köylünün kültür seviyesi göz önünde tutularak onun anlayabileceği kadar basit ve konuları köy hayatından alınmış olmalıydı. Bunlarda propaganda fikri gayet açık olmalıyd.

- Dokümanter filmler, ülkede Cumhuriyet rejiminin yaptığı büyük bayındırlık işlerini, mevcut tarihi eserleri ve yurdun doğal güzelliğini yurt içinde ve dişında tanıtacak filmlerdi. Bunlar ülke içinde ve dişında her yerde gösterilmeliydi.

- Aktüalite filmleri ile ülkedeki önemli olaylar tespit edilerek hem ülke içinde hem de yurt dişında gösterilmeliydi.

- Çocuklar için filmlerin mevzuları çocuk hayatından alınmalıydı. Bu filmlerle çocuklara vatan sevgisi, yeni rejimin iyilikleri ve ahlaki prensipler telkin edilebilirdi.

- Eğitici-öğretici filmlerle köylülere rasyonel ziraat yöntemlerinin faydaları ve çalışma tarzları öğretilmeliydi. ${ }^{43}$

$42 B C A, 490100 / 1221562$ (Parti propagandası için kullanılacak sinema üzerine yazılmış yazılar ve CHP'nin 27/02/1936 tarihli raporu).

$43 B C A, 490100 / 1221562$ (Parti propagandası için kullanılacak sinema üzerine yazılmış yazılar ve CHP'nin 27/02/1936 tarihli raporu). 
Köylüler için filmler, dokümanter filmler ve aktüalite filmleri diğerlerine göre daha az masraflı filmlerdi. Parti ticari bir amaç gütmeyeceği için, ancak bu tür filmler parti tarafından yapılabilecekti. Diğer filmlerin özel kuruluşlara gösterilecek bazı kolaylıklar karşılığında yaptırılmasının mümkün olabileceği düşünülmüştü. Örneğin propaganda ve kültür filmlerini gösteren sinemaları bu filmleri gösterdikleri sürece vergilerden muaf tutmak mümkündü. Bu kolaylık karşılığında filmi yapan ve fillmi gösterecek olan kuruluşlar, partinin yönergesiyle film çevirmeyi ve göstermeyi kabul edebilecekti. ${ }^{44}$

Proje kapsamında partinin çevireceği filmler için bir teşkilat yapılması gerektiğinden de söz edilmiştir. Böylece temin edilen filmler sinemalarda, halk evlerinde, subay yurtlarında ve özellikle gezici sesli film gösterici makineleri ile en ufak köylerde bile gösterilmeliydi. Bu seyyar sesli sinema teşkilatı parti tarafından yapılmalı ve bunun için bir miktar sesli seyyar sinema makinesi alınarak bunlar Kırklareli, Balıkesir, Kocaeli, Denizli, Afyon, Konya, Ankara, Kayseri, Sivas, Adana, Elaziz, Erzurum, Siirt, Erzincan, Kars, Giresun, Samsun, Sinop ve Zonguldak gibi bölgelere dağıtmalıydı. Bu sinemalar, bu iller ve çevresinde en küçük köylere kadar giderek partinin yapmış veya yaptırmış olduğu propaganda filmlerini göstermeli ve bu suretle köylünün aydınlatılmasına hizmet etmeliydi. Bu gezgin sinema işinde gereken teşkilat projesi için de bir miktar masraf yapılması lazımdı. Bu şekilde bir teşkilat yapılmasının, bütün yurttaşlara partinin prensiplerini anlatmak ve benimsetmek bakımından büyük yardımı olacağına kesin gözüyle bakılmıştı. ${ }^{45}$

Rapordan anlaşılmaktadır ki parti, sinemanın insanlar ve toplum üzerindeki etkilerinin dolayısıyla sinemanın rejimin benimsenmesindeki ve halkın eğitim-öğretimindeki potansiyelinin farkındadır. İlgi ve ihtiyaçlara göre tasnifleri yapılan ve hangi tür filmlerin yapılması ile izletilmesi gerektiği konusunda da araştırma inceleme sonuçlarını paylaşan raporda, doğal olarak bütün bu işlerin yapılabilmesinin sınırlarını mali imkânlar belirlemektedir. Ancak yeni Türkiye'nin yeni sinema salonları açılması, film yapımı ve gösterilmesi gibi konuların bilgi ve deneyim eksikliği yanında ekonomik engellere tak1labileceği öngörülebilir. Bu durumda partinin yöneticileri film yapımına odaklanmayıp, ucuza mal edilebilen ve parti için önemi olan filmlerin özellikle yetişkin eğitimi merkezleri olan halkevleri aracılığıyla gösterilmesini sağlayacaktır.

Sonuç olarak halkevleri istatistiğine göre 1935 yılına kadar hiç fillm gösterimi yapılmadı. 1935 yılından itibaren halkevlerinin sayısının artmasıyla da orantılı olarak film

$44 B C A, 490100 / 1221562$ (Parti propagandası için kullanılacak sinema üzerine yazılmış yazılar ve CHP’nin 27/02/1936 tarihli raporu).

$45 B C A, 490100 / 1221562$ (Parti propagandası için kullanılacak sinema üzerine yazılmış yazılar ve CHP'nin 27/02/1936 tarihli raporu). 
gösterim sayısı yükseldi. 1938 yılında sayıları 209 olan halkevlerinde 1.760 film gösterimi yapıld1. 1.760 filme 804.153 kişi geldiğine göre, film başına seyirci sayısı 490 olarak hesapland1. ${ }^{46}$ Ayrıca 1933 yılında Ankara- Samsun arasında 1.002 km'lik mesafede 44 günlük bir çalışma programı uygulayan Seyyar Terbiye Sergisi girişiminde film gösterileri yapılmıştı. ${ }^{47}$

Halkevlerinde en yaygın olarak gösterilen filmler arasında Sovyetler tarafindan çekilen iki film olduğu söylenmektedir. Sergey Yutkevich ve Lev Arnshtam yönetmenliğindeki Ankara, Türkiye 'nin Kalbi filmi 1933 yılında Cumhuriyetin 10. Y1l kutlamaları sırasında ve sonrasında gösterildi. Diğeri Esther Schub tarafından çekilen Türk Inkılabında Terakki Hamleleri adlı belgeseldi. ${ }^{48}$

Daha sonra halkevlerindeki film gösterimleri ile ilgili bir çerçeve belirleme ihtiyacı duyan CHP, halkevlerindeki sinema faaliyetlerinde amacın sinema aracılığılyla halkın fikir ve zevkini yükseltmek olduğunu, bütün çalışma kollarında olduğu gibi ticari bir amaç güdülmediğini belirtti. Bunun yanında halkevlerinde; partinin göndereceği filmler, hükümetin göndereceği filmler, halkevi idare heyeti tarafından halkın yetişmesi amaçları doğrultusunda sağlanacak filmler gösterilebilecekti. ${ }^{49}$

$\mathrm{Bu}$ dönemde CHP her ne kadar sinema konusunda Sovyet Rusya ile iş birliği yapılıyor izlenimi verse de başka ülkelerle de temasta bulundu. Örneğin 1931 yılında Amerikan sinema piyesleri yazarlarından birinin Türkiye'nin dünkü ve bugünkü hayat1nı gösterir bir film çekmek için yaptığı başvuruya gerekli izin verildi. Türkiye'nin masrafsız olarak tanıtılmasına katkı sağlayabilecek olan filmin senaryosu önce bir komisyon tarafından incelenecek, film çekimleri bittikten sonra da sansüre tabi olacaktı. ${ }^{50}$ Yine Amerika Ziraat Bakanlığı Öğretici Filmler Bürosu tarafından hazırlanan filmlerden, Ziraat Bakanlığı tarafından satın alınmak istenen koleksiyonun alınması onand1. ${ }^{51}$ Yurt dışı kaynaklı sakıncalı bulunan filmlerden biri Almanya'ya aitti. Berlin Film Kumpanyası'nın yapmak istediği filmin tadilat yapılarak dahi olsa çekilmesi uygun görülmediğinden Alman Propaganda Nezareti nezdinde temasta bulunuldu ve filmin yapılmaması hakkında kesin talimat verildi. ${ }^{52}$

46 CHP 1939'da Halkevleri, Ankara, Recep Ulusoğlu Basımevi, 1939, s. 6, 28.

47 Nilgün Abısel, Türk Sineması Üzerine Yazılar, Ankara, Phoenix Yayınları, 2005, s. 51.

48 Savaş Arslan, Cinema in Turkey, New York, Oxford University Press, 2011, s. 42.

49 CHP Halkevleri Çalı̧̧ma Talimatnamesi,y.y., Zerbamat, 1940, s. 14-15.

$50 B C A, 301812 / 18161$ (Bir Amerikan şirketine film çekme izni verilmesi ile ilgili 11/03/1931 tarihli yazı).

$51 B C A, 301812 / 84781$ (Amerika'dan satın alınacak zirai öğretici filmlerin dövizi ile ilgili 02/09/1938 tarihli yazı).

$52 B C A, 301000 / 8656724$ (Abdülhamit isimli filmin yapımı ile ilgili 05/05/1935 tarihli yazı). 
Nitekim Türkiye 1940'ların sonuna kadar öncelikle ithal film tüketimine odakland1. Birinci Dünya Savaşı sırasında ittifakın devam etmesi nedeniyle Alman filmlerinin Türkiye'deki kısa süreli bir üstünlüğünden sonra Amerikan filmlerinin, 1925 ’ten sonra Batı Avrupa ve Sovyet filmleri de ithal ediliyor olmasına rağmen, Türk film pazarında etkili olduğu belirtilmektedir. ${ }^{53}$

\section{Sinemada Mevzuat}

CHP ülkede sinemacılığın 1920'li yıllardaki tecrübelerinin ardından sinemayı propaganda amaçlı kullanmaya yönelik projeler geliştirip uygulamaya çalışırken, bir taraftan da yasal düzenlemelerle sinemanın kurumsallaşmasına yönelik adımları 1930'lardan itibaren atmaya başladı.

İlk olarak 1920'li yıllarda belli bir yaşın altındaki çocukların sinemaya girişlerinin engellenmesi konusunda meclise verilen kanun tekliflerinin içeriği 1930 yılında görüşülen Umumi Hıfzısıhha Kanunu kapsamında değerlendirildi. Böylece on iki yaşın altındaki çocukların sinema, tiyatro, dans salonu ve bar gibi mahallere kabul edilmesi 1930 yılında yasaklandı. Altı yaşından büyük çocukların gündüz terbiyesi veya hususi mahiyette olan sinema ve tiyatrolara gitmesine izin verildi. ${ }^{54}$

$\mathrm{Bu}$ dönemde eğitsel filmler hükümetin en çok üzerinde durduğu film türlerindendi. Cumhuriyet tarihinde eğitsel filmlerin kullanılmasının gündeme gelmesi 1923 yılına kadar uzanmaktadır. İlk iktisat kongresi olan İzmir İktisat Kongresi'nde ziraat ve maarif meseleleri ile ilgili olarak "ahlaka aykırı olmamak kaydıyla yeni bir iletişim aracı olan sinemadan yararlanılması" düşünülmüştü. ${ }^{55}$ Bundan sonra yine 1923 yılında Kazım Karabekir tarafından TBMM'ye getirilen bir tezkerede, ibret yerleri kurulması söz konusu olmuştu. Sinema filmlerinin etkisinin güçlü olması nedeniyle kurulacak ibret yerleri aracılığıyla halka ilmi, fenni, sınaî sinema filmlerinin gösterilmesi öngörülmüştü. Mekteplerin ve halkın anlayış ve kavrayışını açmak için; ilmi, fenni, sınai filmlerin halka gösterilmesi ne kadar lüzumlu ise, ahlaka aykırı filmlerin kontrol altına alınmasında gecikilmesi de o kadar tehlikeli idi. Fakat yeni sinemaların açılabilmesi için bütçe yetersizdi. ${ }^{56}$

1930 yılına gelindiğinde Uluslararası Terbiyevi Sinema Enstitüsü tarafından terbiyevî nitelikteki filmlerin ülkeler arasında gümrük resminden muaf tutulması için

53 Savaş Arslan, Cinema in..., s. 42.

54 TBMM Zabit Ceridesi, C. 18, İnikat: 48, 17/04/1930; TBMM Zabit Ceridesi, C. 18, İnikat: 51, 24/04/1930.

55 Afet İnan, İzmir İktisat Kongresi, Ankara, Türk Tarih Kurumu Basımevi, 1989, s. 22.

56 BCA, 301000/146435 (Şark Cephesi Kumandanı Kazım Karabekir'in 22/08/1923 tarihli tezkeresi). 
düzenlenecek konferansa katılım söz konusu oldu. Ülkede henüz esaslı bir şekilde disiplin altına alınmamış olan sinema işinin, uluslararası ve karşılıklı usullerle düzenlenmesi faydalı olacaktı. Bu sebeple ilerde uluslar arasında kabul edilecek ortak ve karş1lıklı esasların düzenlenmesinde, ülkenin çıkarları aleyhine bir yol izlenmesinin önüne geçmek için ilgililerle iletişime geçilmesi düşünüldü. ${ }^{57} 1933$ yllında Terbiyevi Mahiyeti Haiz Filmler Hakkındaki Sözleşme Projesi'ni görüşmek üzere Cenevre'de gerçekleşecek toplantıya katılması için delege gönderilmesine karar verildi. ${ }^{58}$

1938 y1lı haziran ayında mecliste, Terbiyevi Mahiyeti Haiz Filmlerin Milletler Arasında Intişarını Kolaylaştırmak İçin Cenevre'de Akdolunan Beynelmilel Mukavelenameye Iltihakımı Hakkında Kanun tasarısı görüşüldü. Tasarıda belirtilen gerekçeye göre; 11 Ekim 1933 tarihinde Cenevre'de imzalanan bu sözleşmeye katılınması durumunda, eğitimle ilgili filmler imal ve ihraç eden ülkeler arasında bulunulmadı̆̆ından, sözleşmeye fiilen bağlanmak ekonomik açıdan faydalı olmayacağı gibi dışardan getirtilecek bu tür filmler için bir pazar haline gelinebilecekti. Ama kanunda ithali istenecek bu tür filmlerin niteliğinin tespiti denetim komisyonları aracıllğıyla her ülkenin kendi resmî makamları tarafından sağlanacağından bu sakınca ortadan kaldırılabilirdi. $\mathrm{Bu}$ durumda sözleşmeye katılınması halinde başlıca ihracat ürünlerinin dışarda propagandasını sağlamak için filmler yaptırılması düşünüldüğünden bu tür fillmlerin gümrük resmi ödenmeden ithali mümkün olabileceğinden, önemli bir fayda sağlanacağı hesaplanarak kanun kabul edildi. ${ }^{59}$

Bu konuyla ilgili olarak Öğretici ve Teknik Filmler Hakkında İktisat Vekâleti tarafindan hazırlanan ve İcra Vekilleri Heyeti tarafından 1935 yılında tadil edilerek meclise sunulması kararlaştırılan kanun tasarısının gerekçesinde, tasarının aslında ülkenin iktisat mücadelesine katkısı nedeniyle gündeme getirildiği anlaşılıyordu. Gerekçeye göre, kurulmaya çalışılan millî iktisat yapısı ve ülkenin kalkınma savaşında önemli olan ihracat işi en önemli millî meseleydi. Rasyonel bir ihracatı gerçekleştirmek için teşkilat, pozitif bilgi, ekme, yetiştirme, iyileştirme, toplama, ayırma, nakletme, muhafaza etme, kredi bulma ve piyasalara planlı şekilde sevk etme tekniğine dayanan bir ihracat yapılmalıydı. Ülkede ekonomik anlamda ilerlemek ve sürekli bir kalkınma oluşturabilmek için sadece söz ve yazı kullanmak yeterli değildi. Alınan tedbirlerin ve gösterilen yolların uygunluğunun halka canlı bir şekilde gösterilmesi gerekiyordu. Bu konuda tecrübeli

57 BCA, 301000/1464316 (Roma'daki Uluslararası Terbiyevi Sinema Enstitüsü tarafından düzenlenecek konferans ile ilgili 29/07/1930 tarihli yazı).

$58 B C A, 301812 / 374815$ (Cenevre'de terbiyevi mahiyeti haiz filmlerle ilgili toplantı hakkında 24/06/1933 tarihli yaz1).

TBMM Zabit Ceridesi, C. 26, İnikat: 82, 28/06/1938; Resmî Gazete, 15 Temmuz 1938, S. 3960. 
olan İtalya, Kanada, Avustralya, Almanya, İngiltere gibi ülkelerin ilerleme safhalarının incelenmesi gerekiyordu. ${ }^{60}$

Öğretici ve Teknik Filmler Hakkında kabul edilen 3122 sayılı kanuna göre; devlet daireleri tarafindan getirilen teknik ve öğretici filmler ve bu filmleri göstermeğe özgü parlör amplifikatörlü ve sesli film tesisatlı otomobiller, sessiz sinema ve projeksiyon makinaları ve sinema filmi almağa ve yapmağa yarayan makina ve aletler ile boş filimler her türlü vergi ve resimlerden muaf olarak ülkeye sokulacaktı. En önemlisi, sinemalarda esas filmlerle beraber teknik ve öğretici filmlerin gösterilmesi de mecburi hale getirildi. Devlet daireleri tarafindan ülke içinde yaptırılan veya ülke dişından getirilen bu türden filmlerden uygun görülenlerini hükümet, sinemacılara ücretsiz vermeye yetkili olacaktı. Sinemacılar bunları teknik ve öğretici filmler yerine geçmek üzere göstermeye mecburdu. ${ }^{61}$

Hükümet, sinemanın gelişmesinin önündeki mali engelleri ortadan kaldırmak için de birtakım çalışmalar yapıyordu. Örneğin 1930 yılında halkı aydınlatacak araçlardan olan sinemanın ülkenin uzak köşelerine kadar ulaştırılmasını sağlamak için, Maarif Vekâleti'nin 1930 yılı bütçesine söz konusu olan ödenekle satın alınması kararlaştırılmış olan seyyar sinemanın kambiyo kararından hariç olarak 5.000 liraya kadar satın alınması konusunda yetkilendiren bir kararname kabul edildi. ${ }^{62}$

Sinemada vergi indirimleri ile ilgili olarak ise 1930 yılında tiyatro ve sinema biletlerinden yalnız \%10 oranında vergi alınması hakkındaki kanun teklifi meclise havale edilen evraklar arasında yer almıştı. Söz konusu kanun teklifine ait 1931 yılında kabul edilen Dâhiliye, Maarif, Maliye ve Bütçe encümenleri mazbataları gerekçesinde sinemanın eğitsel yönüne vurgu yapılarak şöyle deniyordu:

“...Tiyatro ve sinemalar medeniyete ve özellikle halkın sosyal eğitimine ve ahlakını düzeltmeye hizmet etmektedirler. Eğitime katkıları ise Harf İnklâbında sinemaların matbuatın hizmetlerinin önüne geçtiği zaman görülmüştür. Gazeteler günlük kırk elli bin kişiye ulaşırken, sinemalar tüm Türkiye'de günlük en aşağı yarım milyon halka yeni harflerin okunmasını ögretmişlerdir. İlmî, fennî, siyasî, içtimaî büyük bir propaganda vasitası olan tiyatro ve sinemalara hükümetin de daha çok önem vermesi gerekmektedir. Bundan dolay tiyatro ve sinemalar eğitim-ögretimin bir şubesi sayllarak eğitim-ögretime verilen destek kadar tiyatro ve sinemalara da destek vermek farzdir...Oysa Türkiye'de tiyatro ve sinemalar dünyanın hiç bir ülkesinde alınmayan yüksek vergilerin ă̆ırlı̆̆ altında ezildiklerinden gerilemektedirler... Beş altı sene evvel İstanbul'da

60 TBMM Zabit Ceridesi, C. 16, İnikat 32, 03/02/1937.

61 TBMM Zabit Ceridesi, C. 16, İnikat 32, 03/02/1937; Resmî Gazete, 18 Şubat 1937, S. 3537.

$62 B C A, 301812 / 135110$ (Maarif Vekaleti bütçesinden ödenmek üzere getirtilecek seyyar sinema ile ilgili 24/07/1930 tarihli yaz1). 
sayllarl yüz otuza varan tiyatro ve sinemalardan ancak kırk tane kalabilmesi bunu ispat etmektedir... Türkiye'de bir sinema ve tiyatro irili ve ufakl 24 adet vergi vermeğe mecburdur..."

Kanunun gerekçesinde bazı Avrupa ülkelerinin sinema vergilerinden örnekler verildikten sonra Türkiye'deki \%47 oranında verginin dayanabilecek düzeyden fazla olduğu, eğitim-öğretimin bir şubesi olduğu kadar aynı zamanda bir ticari kuruluş kabul edilen sinema ve tiyatroların bu şartlar altında Türkiye' de gelişemeyeceği vurgulanıyordu. ${ }^{63}$

Meclisteki bu çalışmayla eş zamanlı olarak bir TBMM Kararı da Resmî Gazete' de yayınlandı. Ülkeye getirilecek sinema filmlerinin inkılabın amaçlarına, toplumsal yapıya uygun olmasını ve özellikle çocukların ve gençlerin terbiyesine ve aydınlanmasına hizmet eden filmler hazırlayacak kuruluşların daha fazla "müsaadeye mazhar edilmelerini” sağlayacak surette hükümet tarafından bir kanun layihası hazırlanmasına karar verildi. ${ }^{64}$

1932 yılında faaliyetlerine başlayan halkevleri, sinemanın rejimin propagandasında kullanılması için en ideal yerlerdi. Bunun için 1933 yılında halkevleri adına ithal edilecek radyo ve sinema makineleri hakkında bir kanun teklifi gündeme getirildi. Kanun teklifinde ifade edildiği üzere; belirli düşüncelerin genelleştirilmesi ve halkın aydınlanması için radyo ve sinemalardan sağlanacak fayda önemliydi. Birer kültür kuruluşu olan halkevlerinin herkese yaymakla yükümlü oldukları düşüncelerin halk arasında genelleştirilmesini sağlamak için bu araçlardan faydalanılması gerekiyordu. Ülkenin hemen her tarafında kurulan fakat bu imkândan mahrum olan halkevlerinin bu araçlara sahip olmaları, sadece halkevlerinin amaçlarının gerçekleşmesi açısından değil, gerektiği her durumda bu araçlardan faydalanmak gibi daha genel bir fayda sağlayacaktı. Bu nedenle halkevleri teşkilatının bu araçlarla donatılmalarını sağlamak ve özendirmek için devletçe bazı izinler verilmesi uygundu. Ancak bu fedakârlıklar halkevlerinin ihtiyaçları ile sınırlı kalacaktı. Sunulan teklif yasalaştı. Halkevleri için ithal edilecek alıcı ve verici radyo makineleri, bunların cihazları ile parçaları, sinematograf ve projeksiyon cihazları, inikas fenerleri ile bunların parçalarından gümrük ve muamele vergileri ile oktruva resmi alınmayacaktı. Bu kapsama girecek ürünler ihtiyaca göre Maarif Vekâleti’nden verilecek listelere uygun olarak ithal edilecekti. ${ }^{65}$

Kısa bir süre sonra halkevleri tarafından getirilecek sinema ve radyo makinelerinin gümrük muafiyeti hakkındaki 27 Nisan 1933 tarih ve 2154 sayılı kanunun ikinci

63 TBMM Zabit Ceridesi, C. 17, İnikat: 35, 13/03/1930; TBMM Zabut Ceridesi, C. 24, İnikat: 21, 15/01/1931, 32; TBMM Zabit Ceridesi, C. 24, İnikat: 22, 19/01/1931.

64 Resmî Gazete, 27 Kanunusani 1931, S. 1710.

65 TBMM Zabut Ceridesi, C. 14, İnikat: 39, 20/04/1933; Resmî Gazete, 27 Nisan 1933, S. 2386. 
maddesine göre Maarif Vekâleti'nden verilecek listelere göre gümrük ve muamele vergilerinden muaf olarak ithal edilecek alet ve cihazların, 120.000 liraya kadar İktisat Vekâleti'nin izni ile sınırlama harici ülkeye sokulmasına izin verilmesine ilişkin tezkere, 10/06/1933 tarihinde kabul edildi. ${ }^{66}$ Daha sonra halkevleri için ithal edilecek radyo ve sinema makinelerinin muamele vergisi, gümrük ve oktruva resimlerinden istisnas1 hakkındaki 2154 numaralı kanunun birinci maddesine bir tefsir fikrası kabul edildi. Buna göre halkevleri için getirilecek seyyar sinema ve radyo makinelerine mahsus ve bunlarla cihazlanacak otomobil ve nakil vasitaları, bu sinema ve radyo makinelerinin teferruatından sayılacaktı. ${ }^{67}$

Vergi indirimleri yoluyla ülkede sinemanın yaygınlaştırılması ile ilgili yaklaşım Sovyetler'den ithal edilecek sinema makinelerine de yansıdı. 22/12/1934 tarihinde kabul edilen kanuna göre Sovyet Sosyalist Cumhuriyetleri Birliği'nin Millî İktisat ve Tasarruf Cemiyeti'ne armağanı olan sesli sinema makinesi ile parçaları ve teferruatı vergi ve resimsiz olarak gümrükten geçecekti. Hükümetin bu kanunla ilgili gösterdiği gerekçeye göre; iktisat ve tasarruf ülkülerini halka yaymakta Millî İktisat ve Tasarruf Cemiyeti'nin çok büyük hizmeti vardı. Sesli sinemalar bu hizmeti başarmanın en kıymetli araçlarından biriydi. Bunun için Rusya'dan gelip cemiyete armağan edilen bir sesli sinema film makinesi ile parçaları ve teferruatının gümrük resmi ile başka vergi ve resimlerden muaf tutulması uygun görüldü. ${ }^{68}$

1938 yılı ortalarında tekrar tiyatro ve sinemaların gelişmesine katkı sağlayacak olan başkaca vergi indirimleri ile ilgili yasal düzenlemeler de oldu. Önce Plajlardan, Panayır ve Sergilerdeki Tiyatro, Sinema, Sirk ve Konserlerden Alinmakta Olan Duhuliye Biletlerinden Tayyare Resmi Alınmayacağına Dair Tamim, Resmî Gazete'de yayınlandı. ${ }^{69}$ Ardından Tiyatro ve Sinemalardan Devlet ve Belediyelerce Alinmakta Olan Damga, Tayyare ve Belediye Resimleri ile Darülaceze Hissesinin Miktarına ve Sureti Istifasına Dair Kanun teklifi meclise geldi. Kanun teklifi ile ilgili Bütçe, Dâhiliye ve Maliye encümenlerinin mazbatasında yer alan bilgiler, devletin konuya aynı bakış açısını ortaya koyuyordu. Tasarı, tiyatro ve sinemaların bilet bedelleri üzerinden çeşitli yerlere göre değişen, \%21 ilâ \%28 oranında alınmakta olan damga, tayyare ve belediye resim ve vergileri ile darülaceze hissesinin her yerde seyyanen \%10’a indirilmesini ve bunların tahsil ve kontrol usullerinin düzenlenmesini içeriyordu. Hükümet, halkın ihtiyaçları arasında önemli bir yer tutan, sosyal alandaki etkileri bakımından da devleti yakından ilgilendiren tiyatro ve sinemalara daha

$66 B C A, 301812 / 374320$ (Halkevleri tarafından ithal edilecek sinema ve radyo makineleri ile ilgili 10/06/1933 tarihli yazi).

67 TBMM Zabıt Ceridesi, C. 5, İnikat: 43, 11/10/1935; Resmî Gazete, 14 Teşrinievvel 1935, S. 3131.

68 TBMM Zabit Ceridesi, C. 25, İnikat: 22, 22/12/1934; Resmî Gazete, 29 Kanunuevvel, 1934, S. 2892.

69 Resmî Gazete, 10 Haziran 1938, S. 3930. 
çok ilgi göstermeliydi. Halkın her tabakasının bu yerlerden faydalanmasını sağlamanın yolunun buralara giriş ücretlerini her keseye elverişli bir hale getirmekle mümkün olacağını gören hükümet meseleyi incelemişti. Gelir olarak bu ücretler üzerinden şimdiye kadar alınmakta olan çeşitli vergi, resim ve hisselerden ne kadar fedakârlık yapılabileceğini ve bu verginin bir elden idare ve denetim usulünü getirerek vergi masraflarının azalmasını, buna karşılık da sinemacıların masraf ve kârlarını kontrol ederek gereken indirimi yaptırmak yetkisinin belediyelerin görevleri arasına konulmasını sağlayan hükümleri bu tasarı ile tespit edilmişti. Tasarı esas itibariyle encümen tarafından kabul edildi ve yasalaştı. ${ }^{70}$

Ardından halkın seviyesini yükseltmekte büyük etkileri olan sinemaların daha fazla halkın hizmetine tahsis edilmesini sağlamak amacıyla hariçten getirtilen filmlerin boş ve dolularının kilosundan alınmakta olan gümrük resimlerinin $\% 75$ oranında indirilmesine dair bir kararname onand1. ${ }^{71}$

Ülkede sinemanın gelişmesini isteyen devlet için sinemanın toplum üzerinde yaratabileceği istenmeyen etkileri engellemek de bir o kadar önemli idi. Bunun için 1932 y1lında sinema filmlerinin kontrolüne dair düzenlenen talimatnamenin uygulamaya konulması kabul edilerek, Resmî Gazete' de yayınlandı. Talimatnameye göre gerek dâhilde yapılan gerek hariçten getirilen filmler halka gösterilmeden önce genel olarak kontrole tabi olacaktı. Film kontrolü bir defaya mahsus olmak üzere İstanbul'da üç üyeden oluşan bir komisyon tarafından incelenecekti. Bu inceleme sırasında il polis müdürü ve emniyet müfettişi veya kendisine vekâlet eden bir memur da hazır bulunacaktı. Din propagandasını hedef alan ve askerlik şerefini lekeleyen konuları içeren ve toplumsal terbiye ve adaba ve genel emniyet ve düzene olumsuz etkisi olan ve ülkenin aleyhine iftira içeren ve dost devletlerle olan siyasî ilişkileri bozan filmlerin Türkiye'de gösterilmesine izin verilmeyecekti. Filmleri inceleyen komisyon üyesi arasında anlaşmazlık oluşursa, gösterilmesine izin verildiği halde bunun sakıncalı olduğuna ilgili bakanlık ve makamlar tarafından başvurularak bilgi edinilirse veya film hakkında verilecek kararı sahibi onaylamazsa veya kanaat etmezse film ikinci derecede incelenmek üzere Ankara’ya gönderilecekti. Film burada da yine bir komisyon tarafindan incelenecek ve nihaî karar verilecekti. ${ }^{72} 1933$ yılı sonunda çıkarılan bir kararname ile bu kanunda yer alan yasakların kapsamını biraz daha genişletecek bir fikra eklendi. ${ }^{73}$

70 TBMM Zabit Ceridesi, C. 26, İnikat: 83, 29/06/1938; Resmî Gazete, 16 Temmuz 1938, S. 3961.

$71 B C A, 301812 / 847515$ (Ithal filmlerden alınan gümrük vergisinin indirilmesi ile ilgili 19/08/1938 tarihli yazı).

$72 B C A, 301812 / 294516$ (Sinema filmlerinin kontrolü için hazırlanan yönetmelik ile ilgili 09/06/1932 tarihli yazı); Resmî Gazete, 19 Temmuz 1932, S. 2153.

$73 B C A, 301812 / 41917$ (Sinema filmlerinin kontrolü hakkında yönetmelik ile ilgili 26/12/1933 tarihli yazı); Resmî Gazete, 9 Kanuni sani 1934, S. 2600. 
1936 y1lına gelindiğinde sinema filmlerinin kontrolüne dair olan 9/6/1932 tarih ve 12979 sayı ve 26/12/1933 tarih ve 15489 sayılı talimatnamelerin hükümleri yeni bir kararname ile kaldırıldı. Yeniden hazırlanan talimatnamede birçok hususun titizlikle düşünülüp ayrıntılara yer verdiği görülüyor. Talimatnamenin "Yasaklar" bölümünde; herhangi bir devletin Türkiye'de siyasî propagandasını yapan, Doğu milletleri aleyhinde propaganda yapan, din propagandası yapan filmlerin gösterilmesine izin verilmeyeceği yönünde propagandaya yönelik yasaklar yer aldı. ${ }^{74}$

1934 yılında artarda yayınlanan iki kanunla sinemada denetimin kapsamı genişletildi. Önce radyo, film ve tiyatro gibi kamuoyu ile ilgili olan araçları denetlemek görevi Matbuat Umum Müdürlüğü'nün görevleri arasında sayıld1. ${ }^{75}$ Ardından sinemalar otel, gazino, kahve, içki yerleri, bar, tiyatro, hamam ve plaj gibi umuma mahsus dinlenme ve eğlence yerleri arasında sayıldı. Böylece sinemaların açılması önce polisin araştırması üzerine o yerin en büyük mülkiye amirinin vereceği izne bağland1. ${ }^{76}$

\section{Sonuç}

Sinema XIX. yüzyılın sonunda Batılı ülkelerden çok kısa bir süre sonra Osmanlı Devleti'ne de girmiştir. Başlangıçta sinema filmi gösterimi, sinema salonları açılması, sinema filmi çekilmesi gibi sinemaya ait işler yabancılar tarafından gerçekleştirilmiştir. Birinci Dünya Savaşı yıllarında yabancı ülke örneklerinden de etkilenilerek sinema filmi yapımının ilk örnekleri orduda başlamıştır. Bu yıllarda fark edilen sinemanın insanlar üzerindeki etkisi Cumhuriyet'in ilk yıllarında büyük oranda göz önünde bulundurulmuştur.

Cumhuriyet'in ilk yıllarında bilgi ve tecrübe eksikliği yanında, ekonomik engeller nedeniyle sinemadan istenildiği kadar faydalanılamamıştır. Özellikle 1920'li yıllar bu konuda bir arayış, gözlem ve taklitten öteye gidememiştir. Cumhuriyet'in kuruluşuyla ilgili gelişmelerin yaşandığg 1920'li yıllarda sinema alanında da hazırlık aşaması diyebileceğimiz bir süreç yaşanmıştır. Cumhuriyet Halk Partisi iktidarının ve Atatürk’ün de sinemaya gösterdiği ilginin sonucunda 1920'li yılların tecrübeleri 1930’lu yıllara aktarılabilmiştir. Gerek yerli yapım gerek ithal filmlerde eğitim-öğretim yoluyla ülkenin iktisadi ve sosyal kalkınması hedeflenmiştir. Cumhuriyet rejiminin tanınması ve benimsemesi için yapılan veya yaptırılan filmlerin gösterimi de sinemanın propaganda aracı olarak kullanıldığı kayda değer bir alandır. Bu dönemde oluşturulan sinema mevzuatı da sinemanın ekonomik, sosyal ve siyasi gelişim hedeflerinin amaç ve kapsamına yönelik bir çerçeve sunar.

74 Resmî Gazete, 13 Ağustos 1936, S. 3381.

75 Resmî Gazete, 29 May1s 1934, S. 2713.

76 Resmî Gazete, 14 Temmuz 1934, S. 2751. 
Böylece Cumhuriyet'in ilk y1lları sinemanın bir endüstri ve sanat dalı olarak gelişmesine yönelik değil, propaganda amaçlı kullanımına yönelik çabalara sahne olmuştur.

Hakem Değerlendirmesi: Dış bağımsız.

Çıkar Çatışması: Yazar çıkar çatışması bildirmemiştir.

Finansal Destek: Yazar bu çalışma için finansal destek almadığını beyan etmiş̧ir.

Peer-review: Externally peer-reviewed.

Conflict of Interest: The author has no conflict of interest to declare.

Grant Support: The author declared that this study has received no financial support.

\section{KAYNAKÇA}

\section{Arşiv Kaynaklari ${ }^{77}$}

Türkiye Cumhuriyeti Cumhurbaşkanlığı Devlet Arşivleri Başkanlığı Cumhuriyet Arşivi (BCA)

TBMM Arşivi

\section{Süreli Yayınlar ${ }^{78}$}

Akşam

Hâkimiyet-i Millîye

Resmî Gazete

Vakit

\section{Araştırma Eserler}

CHP Halkevleri Çalışma Talimatnamesi, Zerbamat, 1940.

CHP 1939’da Halkevleri Ankara, Recep Ulusoğlu Basımevi, 1939.

Atatürk, Mustafa Kemal: Atatürk'e Ait Bir Direktif, 1936 (?).

Abısel, Nilgün: Türk Sineması Üzerine Yazllar, Ankara, Phoenix Yayınları, 2005.

Arslan, Savaş: Cinema in Turkey. New York, Oxford University Press, 2011.

Berkes, Niyazi: Propaganda Nedir?, Ankara, Recep Ulusoğlu Basımevi, 1942.

Domenach, Jean-Marie: Politika ve Propaganda, Çev. Tahsin Yücel, İstanbul, Varlık Yayınlar1, 2003.

Dorsay, Atilla: Sinema ve Çă̆ımız, İstanbul, Remzi Kitabevi, 1998.

Egeli, Münir Hayri: Atatürk’ün Bilinmeyen Hatıraları, İstanbul, Yenilik Basımevi, 1954.

77 Faydalanılan arşiv kaynaklarına ait detaylı bilgiler dipnotlarda belirtilmiştir.

78 Faydalanılan süreli yayınların sayı, makale/haber başlığı ve sayfa numaraları dipnotlarda belirtilmiştir. 
Evren, Burçak: 100 Years of Turkish Cinema. Ankara, T.C. Kültür Bakanlığı Yayınları, 2014.

Ferro, Marc: Sinema ve Tarih, Türkçesi: Turhan Ilgaz, Hülya Tufan, İstanbul, Kesit Yayınc1l1k, 1995.

Filmer, Cemil: Hatıralar, İstanbul, Emek Matbaacılık ve İlancılık, 1984.

Gürkan, Turhan: Atatürk'ün Uşă̆ının Gizli Defteri (Cemal Granda), İstanbul, Fer Yayınlar1, 1971.

Güvemli, Zahir: Sinema Tarihi- Başlangıcından Bugüne Türk ve Dünya Sineması, İstanbul, Varlık Yayınevi, 1960.

İnan, Afet: İzmir İktisat Kongresi, Ankara, Türk Tarih Kurumu Basımevi, 1989.

Onaran, Âlim Şerif: Türk Sineması, C. 1, Kitle Yayınları, 1994.

Özgüç, Agâh: Başlangıcından Bugüne Türk Sinemasında İlkler, İstanbul, Yılmaz Yayınlar1, 1990.

Özön, Nijat: Türk Sineması Tarihi (Dünden Bugüne 1896-1960), İstanbul, Ekicigil Matbaas1, 1962.

Özön, Nijat: Türk Sineması Kronolojisi (1895-1966), Ankara, Bilgi Yayınevi. 1968.

Öztürk, Serdar: "Erken Cumhuriyet Yıllarında Sinema Konusunda Başarısız Kalmış İki Girişim: Çekilemeyen İki Propaganda Filmi (1939) ve İbret Yerleri Projesi (1923)”, Selçuk Illetişim, 3-3, 2004, ss. 77-82.

Scognamillo, Giovanni: Cadde-i Kebir'de Sinema, İstanbul, Metis Yayınları, 1991.

Şener, Erman: Kurtuluş Savaşı ve Sinemamız, Dizi Yayınları, 1970.

Teksoy, Rekin: Rekin Teksoy'un Sinema Tarihi, C. 1, İstanbul, Oğlak Yayıncılık ve Reklamcilik, 2009.

Tepedenlioğlu, N. Nazif: Bir Millet Uyanıyor, İstanbul, Kanaat Kütüphanesi, 1933(?).

\section{Elektronik Kaynaklar}

“Türk Dil Kurumu Sözlükleri”, (Çevrimiçi), sozluk.gov.tr, 17 Aralık 2019. 